Article

\title{
Enrichment of Logging Gaps with a High Conservation Value Species (Pericopsis elata) in a Central African Moist Forest
}

\author{
Dakis-Yaoba Ouédraogo ${ }^{1, \dagger}$, Adeline Fayolle ${ }^{1, \dagger}$, Kasso Daïnou ${ }^{2}$, Charles Demaret ${ }^{1}$, \\ Nils Bourland ${ }^{1}$, Paul Lagoute ${ }^{3}$ and Jean-Louis Doucet ${ }^{1, *}$
}

1 Département BIOSE, Gembloux Agro-Bio Tech, Université de Liège, Gestion des Ressources Forestières, B-5030 Gembloux, Belgium; E-Mails: dakis.ouedraogo@gmail.com (D.-Y.O.); adeline.fayolle@ulg.ac.be (A.F.); charlesdemaret48@gmail.com (C.D.); nils.bourland@aigx.be (N.B.)

2 Nature + asbl, Rue Bourgmestre Gilisquet 57, B-1457 Walhain-St-Paul, Belgium; E-Mail: kdainou@ulg.ac.be

3 Pallisco SARL, Avenue des Cocotiers 478, BP 394 Douala, Cameroun; E-Mail: exploitation@pallisco-cifm.com

$\dagger$ These authors contributed equally to this work.

* Author to whom correspondence should be addressed; E-Mail: jldoucet@ulg.ac.be; Tel.: +32-81-62-26-48; Fax: +32-81-62-23-42.

External Editor: Plinio Sist

Received: 4 November 2014; in revised form: 27 November 2014 / Accepted: 1 December 2014 / Published: 5 December 2014

\begin{abstract}
In central Africa, most of the timber species require high light at the seedling stage for survival and growth. Forest managers face a regeneration shortage of these light-demanding timber species. To achieve long-term sustainability, there is a need for enrichment methods combining low cost and high species performance. The aim of this study was to assess the performance of Pericopsis elata seedlings in enriched logging gaps in Cameroon. Over five years; the survival and size of each seedling was monitored in 27 logging gaps that were either left without maintenance or cleared. Gaps were relatively small with an average total area of $155 \mathrm{~m}^{2}$. We found that planted seedlings of $P$. elata performed well in logging gaps. Even without any maintenance $61 \%$ of the planted seedlings survived after five years with an average annual diameter increment of $0.28 \mathrm{~cm}$. P. elata appeared to be a good candidate species for enrichment in logging gaps. We demonstrated
\end{abstract}


that the seedlings of $P$. elata tolerated a wide range of soil conditions but that their performance was strongly influenced by light availability (gap clearance), suggesting potentially improved performance of $P$. elata in high light environments such as in plantation or larger gaps.

Keywords: assamela; plantation; silviculture; canopy gaps; seedling growth; Cameroon; light; regeneration

\section{Introduction}

Increasing conversion of tropical African forests into crops for agriculture or mining requires knowing how to maintain the economic value, the carbon stock and the biodiversity of natural forests [1]. National regulation measures have been introduced in tropical countries to improve forest management and to guarantee the sustainable harvest of timber resources. For instance, forest companies in Central Africa have to develop management plans including recovery rate calculations, adapted rotations, increased harvest diameter limits and reduced impact logging techniques [2]. Nevertheless, a long-term decline in the population of most timber species is predicted [3].

In the first-time-logged forests, managers face two major issues: (i) how to recover, if ever, the timber volume accumulated for centuries within a single felling cycle; (ii) the regeneration shortage of high-value light-demanding timber species [4]. In Central Africa, most timber species require high light levels at the seedling stage for survival and growth [5-8]. However, to minimize the environmental impacts of logging on forest stands and soils, most logging companies adopted reduced impact logging techniques that offer many advantages (e.g., limited soil compaction and erosion) but considerably reduce canopy openness [3] and produce very small logging gaps (less than $300 \mathrm{~m}^{2}$, [9]). If an increase of the felling intensity could stimulate both the growth and the survival of future crop trees [4], it will not be sufficient to improve the regeneration of commercial species that are generally outcompeted by the regeneration of non-commercial tree species [10-12]. In this context, the long-term sustainability of felling cycles can be achieved through enrichment planting of valuable timber species [13,14]. Forest managers identified this need a few decades ago and several trials were performed [15]. But due to the high cost to implement and maintain enrichment planting, most of the initiatives were abandoned. There is thus a need for new-generation silvicultural experiments using native timber species and combining low cost and high species performance (but see [9,16-18]), especially for several logging companies under the independent FSC (Forest Stewardship Council) certification which have to implement regular planting activities (FSC-STD-CB-01-2012 Regional Standard).

Up to now, only a few results have been published on the enrichment of logging gaps in African moist forest [9]. In south-eastern Cameroon, it has been demonstrated that seedlings of Baillonella toxisperma (moabi) introduced in logging gaps had high growth and survival rate ( $>90 \%$ after 30 months; [9]). This result suggests that the method is promising, and the light-demanding and high-value timber species Pericopsis elata (Harms Meeuwen) should be a good candidate species for developing the technique of enriched logging gaps in Central Africa. Due to the overexploitation during the five past decades, P. elata is now included in CITES Appendix II and recorded as "Endangered" in the IUCN Red 
List [19]. The regeneration shortage of this extremely sensitive species has already been highlighted [5]. Hence, enrichment planting using this species has been suggested to ensure its sustainable exploitation [20,21].

The aim of this study was to assess the performance (in terms of growth and mortality) of nursery-raised seedlings of $P$. elata in enriched logging gaps in south-eastern Cameroon. It has been previously demonstrated that regular cutting of the competing vegetation greatly improves the performance of planted seedlings in logging gaps [9,22]. Hence, we additionally analyzed the differences in performance between various degrees of clearance after removing a potential confounding effect of the site (soil, gap size and age).

\section{Materials and Methods}

\subsection{Study Site}

The study was conducted in the forest managements units 10-041, 10-039, and 10-030 (totaling 384,000 ha) managed by the Pallisco company. The study site is located in the province of East, Republic of Cameroon, in the eastern side of the Dja reserve (between $3^{\circ} 10^{\prime}-3^{\circ} 44^{\prime} \mathrm{N}$ and $13^{\circ} 20^{\prime}-13^{\circ} 52^{\prime} \mathrm{E}$ ). The annual rainfall is up to $1640 \mathrm{~mm}$, with two distinct rainy seasons (August to November and March to June) and, according to the Worldclim data [23], the mean annual temperature is $23.1^{\circ} \mathrm{C}$. Altitude varies from 600 to $760 \mathrm{~m}$. Soils are derived from metamorphic rocks and are mainly ferralitic red or typical yellow in color. Forest canopy is dominated by species of the Meliaceae, Sterculiaceae (now included in Malvaceae) and Ulmaceae families indicating a strong floristic affinity with the semi-deciduous forests $[24,25]$.

\subsection{Studied Species}

Pericopsis elata (Harms) Meeuwen (assamela / afrormosia, Fabaceae) can reach a diameter of $130 \mathrm{~cm}$ and 40-50 $\mathrm{m}$ in height, and shows interesting wood technical properties such as dimensional stability and good natural durability [21]. The species is currently logged in Cameroon and in the Democratic Republic of Congo [26]. In the study area P. elata shows a unimodal distribution of diameters (dominated by medium-sized trees) typical of the long-lived light-demanding species that currently suffer a regeneration shortage (Figure 1a). Indeed, $P$. elata is generally classified among non pioneer light-demanding species $[5,11,27]$. The germination of seeds is quick, both in forest understory and in small gaps, but seedlings survive only in openings and rapidly die in deep shade [5,28]. Boyemba [29] highlights strong light requirements at seedling and sapling stages, and suggests forest openings of at least $1000 \mathrm{~m}^{2}$ for the establishment of the species. $P$. elata is hermaphroditic and a gregarious species [21] with a patchy distribution in the study area (Figure 1b). 
Figure 1. (a) Diameter distribution of Pericopsis elata in the area managed by the Pallisco logging company in south-eastern Cameroon; (b) Spatial distribution of $P$. elata in the study site along management inventory line-transects (diameter at breast height $\geq 20 \mathrm{~cm}$ ).

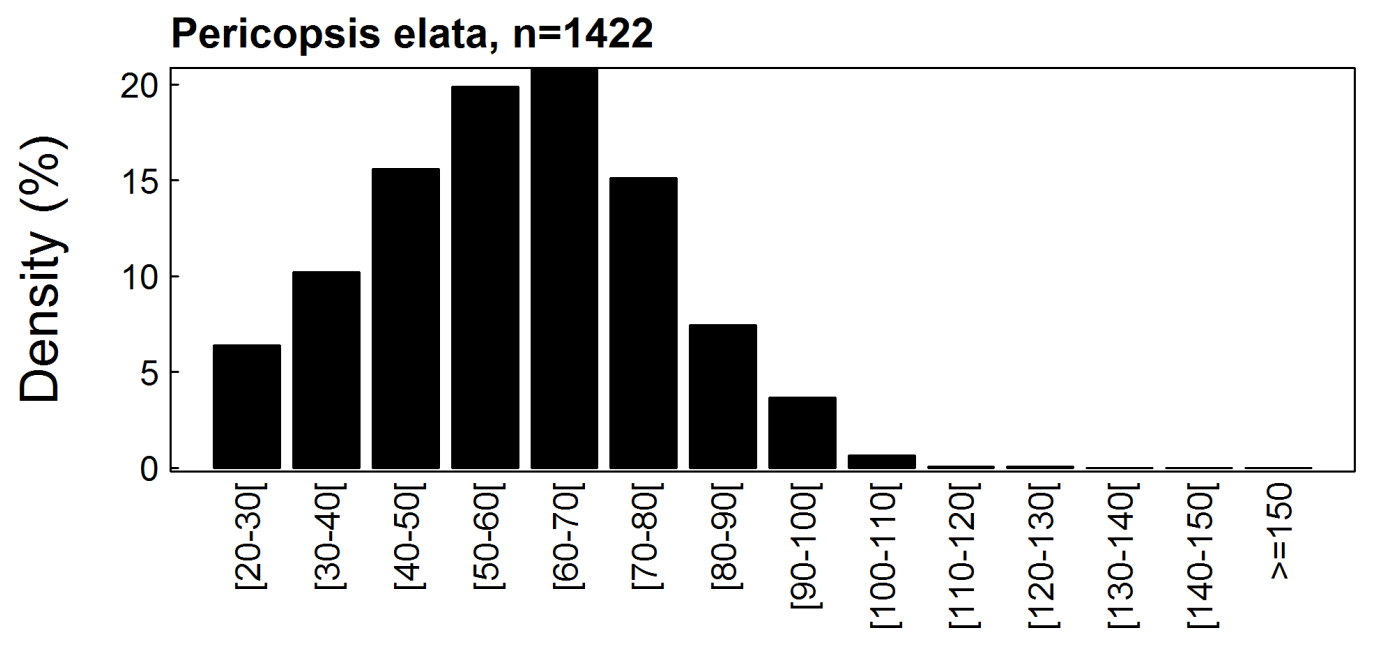

(a)

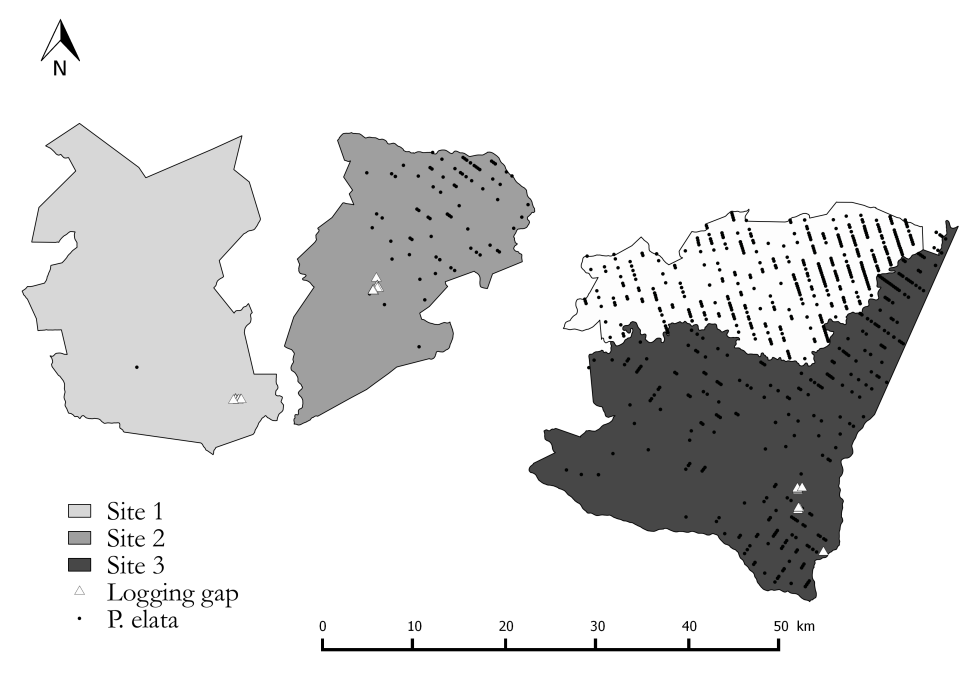

(b)

\subsection{Enrichment of Logging Gaps}

A total of 27 logging gaps located in three forest management units (hereafter referred as site 1, site 2 and site 3) were selected to conduct an experiment of enrichment planting, with nine gaps per site (Figure 1b). P. elata is absent from site 1 while abundant in site 3 . Two hypotheses can be invoked to explain the spatial pattern of $P$. elata. The first hypothesis corresponds to the existence of climate and/or soil gradients. The second hypothesis corresponds to the colonization from a past Congolian refugia during forest fragmentation of the Pleistocene, a phenomenon that has shaped the spatial and genetic structure of tree populations [30]. Selected gaps were 5 to 12 months old. In the field, the boundaries of the gap were determined from both (i) the projection of the canopy of surrounding trees with a diameter 
at breast height $(\mathrm{dbh}) \geq 20 \mathrm{~cm}$, and (ii) the presence of seedlings/saplings belonging to early pioneer species (e.g., Musanga cecropioides and Macaranga sp.). The surface of each logging gap was determined with a $2 \times 2 \mathrm{~m}$ grid fixed on the ground with ranging poles. The logging gaps selected were relatively small, with an average total area of $155 \mathrm{~m}^{2}$ (standard deviation $\mathrm{s}=17 \mathrm{~m}^{2}$ ). Within each gap, two distinct parts were distinguished in the field: The proximal part of the gap, that is the area where the tree trunk had fallen down and had been off-loaded by the logging machines, and the distal part of the gap, that is the area delineated by the foliage crown of the tree lying on the ground. As branches and leaves still covered much of the distal part and thus inhibit any regeneration prior to decomposition, only the proximal part of the gap was enriched.

Nursery-raised seedlings of $P$. elata $(n=285)$ were planted between 2007 and 2008 in $4 \times 2 \mathrm{~m}$ grid cells in the proximal part of the 27 logging gaps, and the position of each seedling was recorded. The mean height and diameter of the planted seedlings was $59 \mathrm{~cm}$ (standard deviation $\mathrm{s}=16 \mathrm{~cm}$ ) and $6 \mathrm{~mm}$ ( $\mathrm{s}=2 \mathrm{~mm}$ ), respectively. Before planting, competing vegetation was totally removed using a machete and the ground was cleared from any debris. Over five years, seedlings height and basal diameter were bi-annually measured, and dead seedlings were recorded. Plant height was measured to the nearest $\mathrm{cm}$ with a $6 \mathrm{~m}$ rule, and basal diameter to the nearest $\mathrm{mm}$ with calipers. In each of the three sites, a total of three gaps were kept as control, three gaps received minor clearance, and the three other gaps received major clearance. Minor clearance consisted in bi-annual clearing of all plants in a radius of one meter around $P$. elata seedlings, and major clearance in bi-annual clearing of all plants in the gap except the planted seedlings of $P$. elata.

A composite soil sample (from five sub-samples collected from 0 to $20 \mathrm{~cm}$ depth) for each gap was analyzed for textural and chemical composition by the soil laboratory of the Université Libre de Bruxelles, Belgium, following standard protocols [31]. Soil texture (\% clay, sand, and silt), bulk density $\left(\mathrm{bd}, \mathrm{g} / \mathrm{cm}^{3}\right)$, soil $\mathrm{pH}$ in both water and $\mathrm{KCl} 1 \mathrm{~mol} \cdot \mathrm{L}^{-1}$, and organic matter $(\mathrm{OM})$ were measured. Soil content of $\mathrm{K}, \mathrm{Ca}, \mathrm{Mg}, \mathrm{H}, \mathrm{Al}, \mathrm{Ba}, \mathrm{Co}, \mathrm{Cr}, \mathrm{Cu}, \mathrm{Fe}, \mathrm{Mn}, \mathrm{Ni}, \mathrm{P}, \mathrm{Pb}, \mathrm{Sr}$, and $\mathrm{Zn}$ was also determined. Cation exchange capacity (CEC) was defined as the sum of exchangeable basic cations $\mathrm{K}, \mathrm{Ca}$, and $\mathrm{Mg}$, and it was used as a measure of soil fertility.

Additional information on canopy openness was collected at the start of the experiment (with the exception of site 1) and after five years. We assessed the presence or absence of vegetation in the following height intervals: $0-10,10-20$, and $>20 \mathrm{~m}$ above each planted (alive or not) seedling [6,9]. The canopy openness was defined as the absence of vegetation directly above the seedling. As a measure of the overall light availability in the gap, we computed the proportion of seedlings that were not overtopped in each gap. It was thus possible to compare the dynamics of canopy closure between sites.

\subsection{Data Analysis}

\subsubsection{Differences between Sites}

To assess the effect of the gap conditions on the performance of $P$. elata seedlings, we tested whether sites significantly differed in gap age, gap size, and soil fertility using Kruskal-Wallis rank sum tests followed by Nemenyi-Damico-Wolfe-Dunn multiple comparison tests [32]. We identified the variation in soil textural and chemical properties with a principal component analysis (PCA). The score of each 
logging gap on the first axis of the PCA was used as an index of soil fertility. All analysis were performed using the R statistical software [33].

\subsubsection{Modeling Seedling Performance}

To quantify species performance we computed the annualized mortality rate $\left(\mathrm{M}\right.$, in $\%$ year $\left.^{-1}\right)$ in each gap following [34]:

$$
\mathrm{M}=\left[1-\left(N_{t} / N_{0}\right)^{(1 / t)}\right] \times 100
$$

with $N_{t}$ the number of alive saplings at time $t, N_{0}$ the initial number of planting seedlings, and $t$ the time at the end of the five years of monitoring. We calculated the relative growth rate (RGR, in $\mathrm{cm} \cdot \mathrm{cm}^{-1} \cdot$ year $^{-1}$ ) in diameter and height for the seedlings that survived until the end of the five years of monitoring following [35]:

$$
\mathrm{RGR}=\left[\ln \left(\operatorname{size}_{t}\right)-\ln (\operatorname{size} 0)\right] / t
$$

with size $t$ the height or diameter at time $t$, and size 0 the height or diameter at the start of the experiment. The RGR expresses growth in terms of rate increase in size per unit of size. As such, it permits more equitable comparisons between seedlings of different size than does absolute growth rate [35]. Indeed, we identified significant differences in seedling height at the start of the experiment between the three sites, with 63 (standard deviation $\mathrm{s}=16), 57(\mathrm{~s}=14)$, and $52(\mathrm{~s}=17) \mathrm{cm}$ height on average in site 1,2 and 3, respectively (ANOVA F $2,282=12.57, p<0.0001, n=285$ seedlings introduced in $9 \times 3=$ 27 gaps).

In order to compare our results with other studies, we additionally computed the height and diameter increment of each seedling over the observation period.

To test the effect of clearance on the seedling performance, we modeled the probability of a seedling to die (mortality) with a generalized linear mixed model (binomial error structure) and the RGR in height and diameter with a linear mixed model. Clearance was specified in the models as a three-level fixed factor (control, minor and major clearance). We accounted for the effect of specific gap environment on seedlings performance by specifying the gap as a random effect on the models' intercept. To estimate the effect of clearance on seedlings performance after removing a potential confounding effect of the site, we also included the site as a fixed factor in the mortality and growth models that are detailed below.

$$
\begin{gathered}
\mathrm{M}_{j} \sim \operatorname{Binomial}\left(1, \pi_{i j}\right) \\
\operatorname{logit}\left(\pi_{i j} \mid \mathrm{b}_{j}\right)=\alpha+\beta_{c}+\theta_{s}+\mathrm{b}_{j} \\
\text { with } \mathrm{b}_{j} \sim \operatorname{Gaussian}\left(0, \sigma^{2} \mathrm{~b}\right) \\
\operatorname{RGR}_{i j}=\alpha+\beta_{c}+\theta_{s}+\mathrm{b}_{j}+\varepsilon_{i j} \\
\text { with } \mathrm{b}_{j} \sim \operatorname{Gaussian}\left(0, \sigma^{2} \mathrm{~b}\right) \\
\text { with } \varepsilon_{i j} \sim \operatorname{Gaussian}\left(0, \sigma^{2}{ }_{\varepsilon}\right)
\end{gathered}
$$

where $\mathrm{M}_{j}$ is the number of dead individuals in a gap $j, \pi_{i j}$ is the probability of seedling $i$ to die in five years after being planted in gap $j, \mathrm{RGR}_{i j}$ is the RGR in height or diameter of seedling $i$ in gap $j, \alpha$ is the model intercept, $\beta_{c}$ is the coefficient for the fixed effect of clearance on seedling performance (three levels), and $\theta_{s}$ is the coefficient for the fixed effect of site (three levels). The three different models 
(for the probability to die, RGR in height and RGR in diameter) were fitted using the lme4 library of the $\mathrm{R}$ software [33], and models' residuals were analyzed to check if the conditions of normality, homoscedasticity, and independency between observations were met. Conditional $R^{2}$, that is the proportion of variability explained by both fixed and random effects, was also computed for the three models [36].

\section{Results}

\subsection{Seedling Performance in Control Gaps}

Without clearance, the seedlings of Pericopsis elata performed relatively well in the nine control logging gaps regularly monitored over five years. With the exception of site 3 , almost $75 \%$ of the planted seedlings survived after five years, and stems reached $3 \mathrm{~m}$ tall (Table 1). In the site 3, only $33 \%$ of the seedlings survived. They were only $1.7 \mathrm{~m}$ tall after five years with a relative growth rate in diameter two-fold beside the rate found in the two others sites (Table 1). This indicates that surviving seedlings in site 3 had suppressed growth.

Table 1. Performance of P. elata in the nine control logging gaps (without any maintenance).

The mean and standard deviation (s) of mortality rate after five years, annualized mortality rate, height of seedlings at plantation and after five years, height and diameter increment, and relative growth rate in height and diameter are given for each site and for all sites (Total). The number ( $n$ ) of planted or survival seedlings is also given. The mean and standard deviation of gap age, size, and number of introduced seedlings are also indicated.

\begin{tabular}{|c|c|c|c|c|c|c|c|c|}
\hline \multirow[t]{2}{*}{ Variable } & \multicolumn{2}{|c|}{ Site 1} & \multicolumn{2}{|c|}{ Site 2} & \multicolumn{2}{|c|}{ Site 3} & \multicolumn{2}{|c|}{ Total } \\
\hline & Mean & $S$ & Mean & $S$ & Mean & $S$ & Mean & $S$ \\
\hline Mortality & & & & & & & & \\
\hline Mortality after 5 years (\%) & 25.8 & 14.8 & 23.3 & 15.3 & 67.2 & 21.8 & 38.8 & 26.2 \\
\hline $\begin{array}{l}\text { Annualized mortality } \\
\text { rate }\left(\% \text { yearr }^{-1}\right)\end{array}$ & 6.0 & 3.9 & 5.4 & 3.9 & 22.9 & 14.2 & 11.4 & 11.5 \\
\hline Growth & & & & & & & & \\
\hline Planted height $(\mathrm{cm})$ & $\begin{array}{c}75 \\
(n=33)\end{array}$ & 23 & $\begin{array}{c}59 \\
(n=30)\end{array}$ & 14 & $\begin{array}{c}54 \\
(n=32)\end{array}$ & 14 & $\begin{array}{c}63 \\
(n=95)\end{array}$ & 20 \\
\hline 5 years height $(\mathrm{cm})$ & $\begin{array}{c}331 \\
(n=24)\end{array}$ & 133 & $\begin{array}{c}296 \\
(n=23)\end{array}$ & 101 & $\begin{array}{c}169 \\
(n=10)\end{array}$ & 76 & $\begin{array}{c}288 \\
(n=57)\end{array}$ & 125 \\
\hline Height increment $\left(\mathrm{cm} \cdot \mathrm{year}^{-1}\right)$ & 50.94 & 26.00 & 47.18 & 19.73 & 24.46 & 13.28 & 44.78 & 23.48 \\
\hline $\begin{array}{l}\text { Diameter increment } \\
\left(\mathrm{mm} \cdot \text { year }^{-1}\right)\end{array}$ & 2.86 & 1.33 & 3.32 & 1.12 & 1.30 & 0.85 & 2.77 & 1.36 \\
\hline $\begin{array}{l}\text { RGR in height } \\
\left(\mathrm{cm} \cdot \mathrm{cm}^{-1} \cdot \text { year }^{-1}\right)\end{array}$ & 0.28 & 0.10 & 0.31 & 0.09 & 0.24 & 0.06 & 0.29 & 0.09 \\
\hline $\begin{array}{l}\text { RGR in diameter } \\
\left(\mathrm{mm} \cdot \mathrm{mm}^{-1} \cdot \mathrm{year}^{-1}\right)\end{array}$ & 0.23 & 0.10 & 0.24 & 0.06 & 0.12 & 0.06 & 0.21 & 0.09 \\
\hline Gap characteristics & & & & & & & & \\
\hline Age (mth) & 6.8 & 0 & 6.6 & 1.9 & 10.4 & 0.32 & 7.9 & 2.1 \\
\hline Area $\left(\mathrm{m}^{2}\right)$ & 121 & 25 & 122 & 25 & 191 & 39 & 145 & 44 \\
\hline $\begin{array}{l}\text { Number of planted } \\
\text { seedlings in a gap }\end{array}$ & 11 & 2.7 & 10 & 0 & 10.7 & 1.2 & 10.6 & 1.5 \\
\hline
\end{tabular}




\subsection{Effect of Clearance}

The models used to assess the effect of clearance on seedling performance taking into account the effect of site were fitted to the data (Appendix Figures A1-A3). The three models explained 30\%, 51\%, and $68 \%$ (including fixed and random effects) of the total variability in seedling probability to die, RGR in height, and RGR in diameter, respectively. Bi-annual clearance of all competing vegetation in the gap (major clearance) significantly increased the performance of $P$. elata seedlings (Figure 2 and Table 2). The probability to die significantly decreased, and both relative growth rate in height and diameter significantly increased, in gaps that received major clearance $(\mathrm{Z}=-3.5, p<0.001, \mathrm{~T}=4.3$, $p<0.001$, and $\mathrm{T}=7.3, p<0.001$ for the probability to die, RGR in height and RGR in diameter, respectively). Minor clearance (i.e., bi-annual clearance of all competing vegetation in a radius of one meter around each seedling) only slightly increased the performance of seedlings. We found a significant effect of the minor clearance on relative growth rate in diameter $(\mathrm{T}=2.5, p=0.014)$, but no significant effect on seedling probability to die and relative growth rate in height $(\mathrm{Z}=-1.7, p=0.10$ and $\mathrm{T}=1.4$, $p=0.16$, respectively).

Figure 2. Height growth trajectory for each seedling of $P$. elata in logging gaps left without any maintenance (control), partially cleared (one-meter around the seedling, minor clearance), and totally cleared (major clearance). The discontinuous height trajectory for several seedlings is due to stem break events.
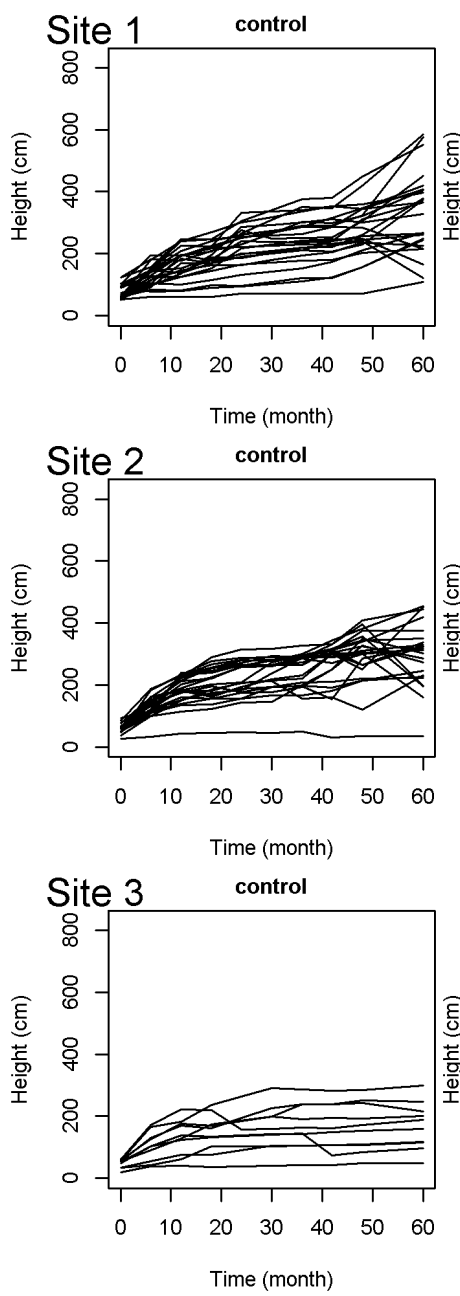
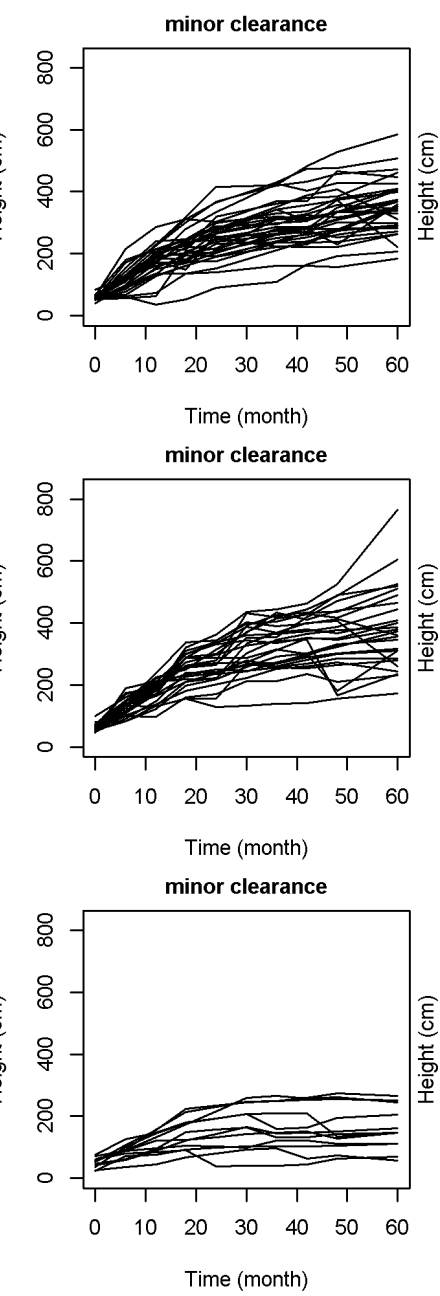

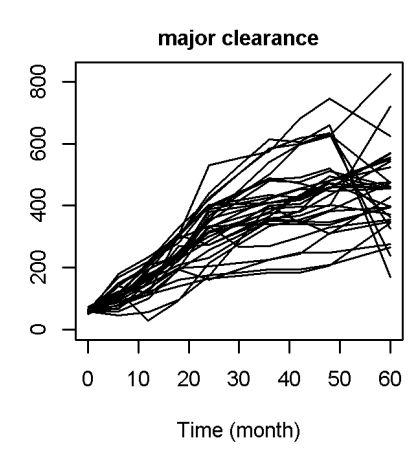

major clearance
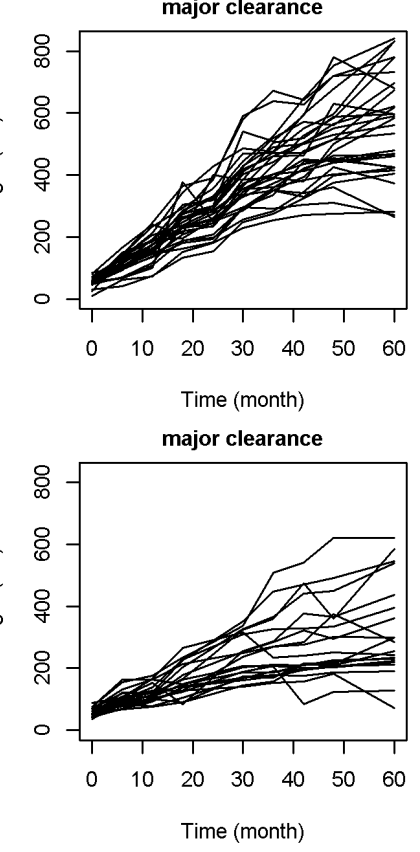
Table 2. Performance of $P$. elata seedlings according to silvicultural treatments in control gaps $(n=9)$, in gaps with bi-annual clearance one-meter around the seedling (minor C., $n=9$ ), and in gaps with bi-annual clearance of all competing vegetation (major C., $n=9$ ). The mean and standard deviation (s) of mortality rate after five years, annualized mortality rate, height of seedlings at plantation and after five years, height and diameter increment, and relative growth rate in height and diameter are given for each silvicultural treatment. The number $(n)$ of planted or survival seedlings is also given. The mean and standard deviation of gap age, size, and number of introduced seedlings are also indicated.

\begin{tabular}{ccccccc}
\hline Variable & Control & \multicolumn{2}{c}{ Minor C. } & \multicolumn{2}{c}{ Major C. } \\
\hline & Mean & $\boldsymbol{S}$ & Mean & $\boldsymbol{S}$ & Mean & $\boldsymbol{S}$ \\
\hline Mortality & & & & & & \\
Mortality after 5 years (\%) & 38.8 & 26.2 & 26.9 & 25.1 & 14.4 & 20.1 \\
Annualized mortality rate (\% year $\left.{ }^{-1}\right)$ & 11.4 & 11.5 & 7.1 & 7.5 & 3.5 & 5 \\
\hline Growth & & & & & & \\
Planted height (cm) & $63(n=95)$ & 20 & $55(n=96)$ & 13 & $56(n=94)$ & 13 \\
5 years height (cm) & $288(n=57)$ & 125 & $331(n=70)$ & 130 & $458(n=81)$ & 179 \\
Height increment $\left(\mathrm{cm} \mathrm{year}^{-1}\right)$ & 44.78 & 23.48 & 54.82 & 25.67 & 80.32 & 36.05 \\
Diameter increment $\left(\mathrm{mm} \mathrm{year}^{-1}\right)$ & 2.77 & 1.36 & 4.23 & 2.24 & 8.04 & 4.05 \\
RGR in height $\left(\mathrm{cm} \mathrm{cm}^{-1}\right.$ year $\left.^{-1}\right)$ & 0.29 & 0.09 & 0.34 & 0.09 & 0.41 & 0.11 \\
RGR in diameter (mm mm ${ }^{-1}$ year $\left.^{-1}\right)$ & 0.21 & 0.09 & 0.29 & 0.10 & 0.40 & 0.12 \\
\hline Gap characteristics & & & & & & \\
Age (mth) & 7.9 & 2.1 & 8.3 & 1.6 & 7.9 & 2.0 \\
Area (m ${ }^{2}$ ) & 145 & 44 & 166 & 59 & 149 & 42 \\
gap & 10.6 & 1.5 & 10.7 & 3.0 & 10.0 & 3.3 \\
\hline Number of planted seedlings in a & & & & & &
\end{tabular}

\subsection{Between Site Differences}

We found a significant effect of the site on the performance of the seedlings. Regardless of the silvicultural treatment (control, minor or major clearance), the probability to die was significantly higher in gaps located in site 3 than in the two other sites $(Z=4.1, p<0.001)$ and the RGR in height and diameter were significantly lower than in the two others sites $(\mathrm{T}=-3.3, p=0.0012$ and $\mathrm{T}=-6.8$, $p<0.001)$.

To explain the differential performance of seedlings between sites, and specifically the relatively low performance of seedlings in site 3, we examined the characteristics of the logging gaps. First, the three sites significantly differed in gap age (Kruskal-Wallis $\chi^{2}=20.25, p<0.001$ ) and gap size $\left(\chi^{2}=8.01, p=0.018\right)$, with older and larger gaps in site $3\left(6.8,7\right.$, and 10.4 months, 135,136 , and $188 \mathrm{~m}^{2}$ on average for site 1, 2 and 3, respectively). Second, in site 3, all planted seedlings were overtopped after five years by competing vegetation, while on average 8.6 and $27.8 \%$ of the seedlings still had overhead full light after five years in site 1 and 2, respectively. These results indicate a stronger competitive effect of vegetation regrowth in logging gaps of site 3 than in the two other sites.

We additionally examined the potential role of soil textural and chemical properties to explain seedling differential performance between sites. The first axis of the PCA which explained 39.5\% of the total variance opposed the logging gaps located in site 1 to those located in sites 2 and 3 (Figure 3). Soils 
in sites 2 and 3 had higher clay and organic matter content and lower bulk density than soils in site 1 (Appendix Table A1). Soils in site 3 also had the highest CEC, although differences between site were not significant $\left(\chi^{2}=4.16, p=0.13\right)$. The sum of $\mathrm{K}, \mathrm{Ca}$, and $\mathrm{Mg}$ content (CEC) was on average 0.64, 0.73 , and $0.99 \mathrm{cmolc}_{\mathrm{c}} \cdot \mathrm{kg}^{-1}$ for site 1,2 , and 3, respectively. Thus, soils may be the most fertile ones in site 3 where the seedlings performed the worst.

Figure 3. Principal component analysis (PCA) of soil textural and chemical composition. The first and second axes explained $39.5 \%$ and $16.9 \%$ of the total variance, respectively. (a) Circle of correlations between soil \% sand, clay and silt, \% organic matter $(\mathrm{OM}), \mathrm{pH} \mathrm{H}_{2} \mathrm{O}$, $\mathrm{pH} \mathrm{KCl}$, bulk density (bd), content of $\mathrm{Ca}, \mathrm{Mg}, \mathrm{K}, \mathrm{Al}, \mathrm{H}, \mathrm{Ba}, \mathrm{Co}, \mathrm{Cr}, \mathrm{Cu}, \mathrm{Fe}, \mathrm{Mn}, \mathrm{Ni}, \mathrm{P}, \mathrm{Pb}$, $\mathrm{Sr}$, and $\mathrm{Zn}$; (b) Projections of the scores of the logging gaps (points) and sites (origins of the stars) on the first factorial map of the PCA. Gaps belonging to site 1, 2 and 3 are represented in light grey, grey, and dark grey, respectively.

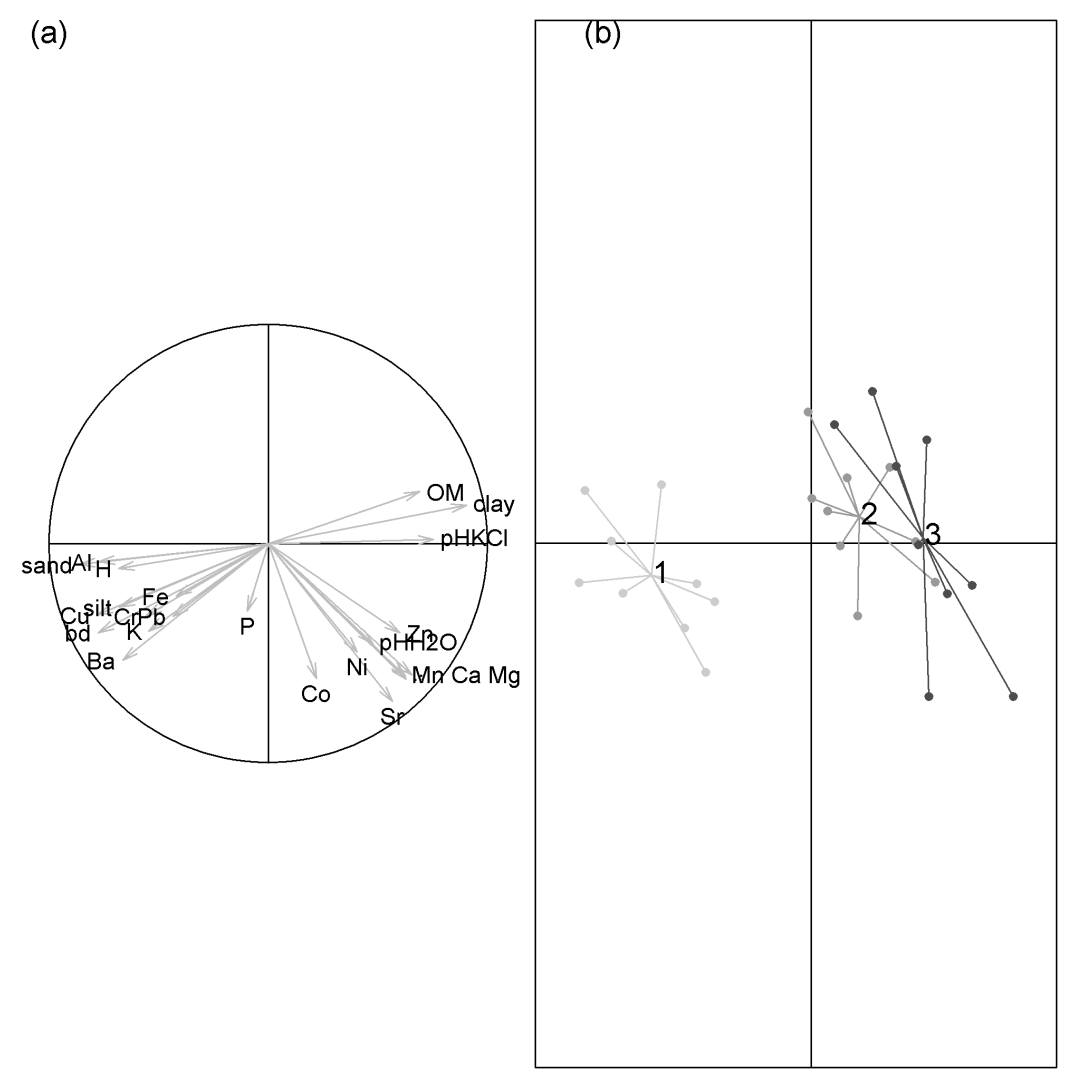

\section{Discussion}

The aim of this study was to assess the performance of nursery-raised seedlings of Pericopsis elata monitored over five years in enriched logging gaps in south-eastern Cameroon. We demonstrated that without any maintenance, the seedlings of $P$. elata performed relatively well. A total of $61 \%$ of the planted seedlings survived after five years with an average annual diameter increment of $0.28 \mathrm{~cm}$ equivalent to the increment of adult trees observed in the study area $(0.31 \mathrm{~cm},[20])$. Furthermore, regular clearing of the whole competing vegetation greatly improved the performance of seedlings. The probability to die was significantly reduced, and both growth in height and in diameter significantly increased. 


\subsection{The Seedlings of P. elata Performed Well in Logging Gaps}

P. elata was found to show surprising ability to survive in logging gaps, even with no maintenance. First, the logging gaps selected for this enrichment experiment were relatively small ( $155 \mathrm{~m}^{2}$ on average) compared to other experiments (e.g., $265.8 \pm 175.4 \mathrm{~m}^{2}$, Cameroon, [9]; from 165 to $455 \mathrm{~m}^{2}$, Brazil, [22]). As the amount of light available generally increases with gap size [22], the amount of light available was probably lower in this study. In Cameroon, seedlings of Baillonella toxisperma introduced in logging gaps with no clearance had high annual growth height $(65.8 \pm 80.0 \mathrm{~cm})$ and survival rate $(98.4 \% \pm 4.8 \%)$ after 30 months indicating that the species performed well in medium size logging gaps (on average $265.8 \mathrm{~m}^{2}$ ) [9]. As for P. elata, it successfully established in small size gaps, and we can reasonably assume that at least one tree would survive until the adult stage. We thus believe that $P$. elata is a good candidate species for enrichment in logging gaps.

In addition, we showed that the seedlings of $P$. elata can persist for a long time in unfavorable growth conditions. In the logging gaps where the seedlings showed the lowest growth performance (site 3, height and diameter growth two-fold reduced), a total of $33 \%$ of the planted seedlings survived after five years. The regeneration shortage of this light-demanding timber species could thus be explained by other hazards faced in the earlier life stages such as seed predation [21]. Through seed collection in the field, seed germination and rising of seedlings in the nursery, and plantation in logging gaps, foresters have the opportunity to level-off the limitations to the natural regeneration and to ensure population recovery after logging. This is of extreme importance for the management of the sensitive species P. elata.

\subsection{Clearance Increases the Performance of P. elata Seedlings}

In agreement with the results of previous enrichments in logging gaps in Africa [9] and Amazonia [22], removing the whole competing vegetation nearby planted seedlings appeared to greatly improve their performance. This result highlights the need for clearance to improve the success of the enrichment in logging gaps, which may, however, be difficult to implement by logging companies for the reasons detailed below. First, the cost of bi-annual major clearance over five years is estimated at $10 \times 2=20$ EUR per gap [9], that is relatively expensive compared to the estimated cost for enrichment without maintenance (5.5 EUR per gap, [9]). Second, logging companies engaged in certification process need to develop plantation activities and limit forest access to poachers by closing logging roads and trails (FSC-STD-CB-01-2012 Regional Standard). Thus, logging gaps could not be regularly cleared once the logging roads and trails are closed.

\subsection{Determinants of between Site Differences}

In this study we showed a differential performance of seedlings between sites, regardless of the silvicultural treatment. The relatively low performance of $P$. elata seedlings in site 3 (only $33 \%$ survival and strong growth suppression) is surprising since the trees with a diameter at breast height $\geq 20 \mathrm{~cm}$ are specifically abundant in this site (Figure 1b). In addition, since the soils in site 3 appeared to be the most fertile ones, with the highest clay content, the relative poor performance of $P$. elata seedlings may not be explained by differences in soil properties, and additional characteristics of the logging gaps of site 3 should be considered. Indeed, logging gaps in site 3 were the oldest (10.4 months on average), and the 
largest (188.4 $\mathrm{m}^{2}$ on average). Measures of the canopy openness also showed that in contrast to the other sites all planted seedlings in site 3 were overtopped by competing vegetation after five years, thus indicating stronger competition with non-commercial species. The higher canopy closure in site 3 than in the two other sites could be either explained by the older age of logging gaps, or by a more dynamic regrowth of the vegetation on more fertile soils. Hence, the relatively poor performance of $P$. elata on more fertile soils may be explained by the higher competition intensity and the low competitive ability of $P$. elata. Indeed on rich soils, $P$. elata which have sympodial growth by reiteration tended to be outcompeted by fast-growing pioneer species such as Musanga cecropioides or Macaranga sp. which have efficient height extension. Conversely, on poor soils, $P$. elata was able to persist in contrast to fast-growing pioneer species.

\section{Conclusions}

The good performance of Pericopsis elata in logging gaps is of extreme importance to favor the population recovery of this light-demanding timber species that do not naturally regenerate in central African moist forests. Enriched logging gaps are however difficult to monitor on the long-term (limited access due to logging roads closure) and the survival of planted seedlings will only be assessed at the next felling cycle. In this study, we demonstrated that the seedlings of $P$. elata tolerated a wide range of soil conditions but that their performance was strongly influenced by light availability (regular clearance of the competing vegetation). This result suggests potentially improved performance of $P$. elata in high light environments such as plantation or larger gaps. Although promising, these results argue in favor of further experiments to define practical guidelines for the forest sector adapted to the autoecology of each timber species and the environmental conditions of the site.

\section{Acknowledgments}

We acknowledge the forest company Pallisco, and specifically Michel Rougeron, Loïc Douaud, Richard Fétéké, Patrice Tekam, and the whole technical team for silvicultural research and operations, especially Crépin Ndjopamdé and Théophile Ayol, for access to the field, the seed collection, the raising of seedlings in the nursery, the plantation, and the regular monitoring of seedlings in logging gaps. We also wish to thank the non-profit-making organization Nature + for logistic support and funding, Yves Brostaux and Nicolas Latte for their helpful support with preliminary analysis, and Thomas Drouet (ULB) for the soil samples analysis. The study was financially supported by FRFC project (F.R.S./FNRS, No. 2.4577.10). Dynamics of light-demanding tree species and grasses in the humid forests of Central Africa in relationship with past anthropogenic and climate disturbances. Dakis-Yaoba Ouédraogo was funded by the research unit Gestion des Ressources Forestières, Gembloux Agro-Bio Tech, Université de Liège.

\section{Author Contributions}

Dakis-Yaoba Ouédraogo, Adeline Fayolle, Kasso Daïnou, Charles Demaret, Nils Bourland and Jean-Louis Doucet conceived the ideas; Jean-Louis Doucet, Nils Bourland, and Paul Lagoute collected the data; Dakis-Yaoba Ouédraogo and Adeline Fayolle analyzed the data and led the writing. All authors commented on the manuscript. 


\section{Appendix}

Figure A1. Residuals of the generalized linear model (binomial distribution) used to model seedlings probability to die. The analysis of models' residuals showed that conditions for normality, homoscedasticity, and independency between observations were correctly met. All observations had Cook's distances $<1$ indicating that no outliers influenced coefficient estimates.

\section{Binned residual plot}

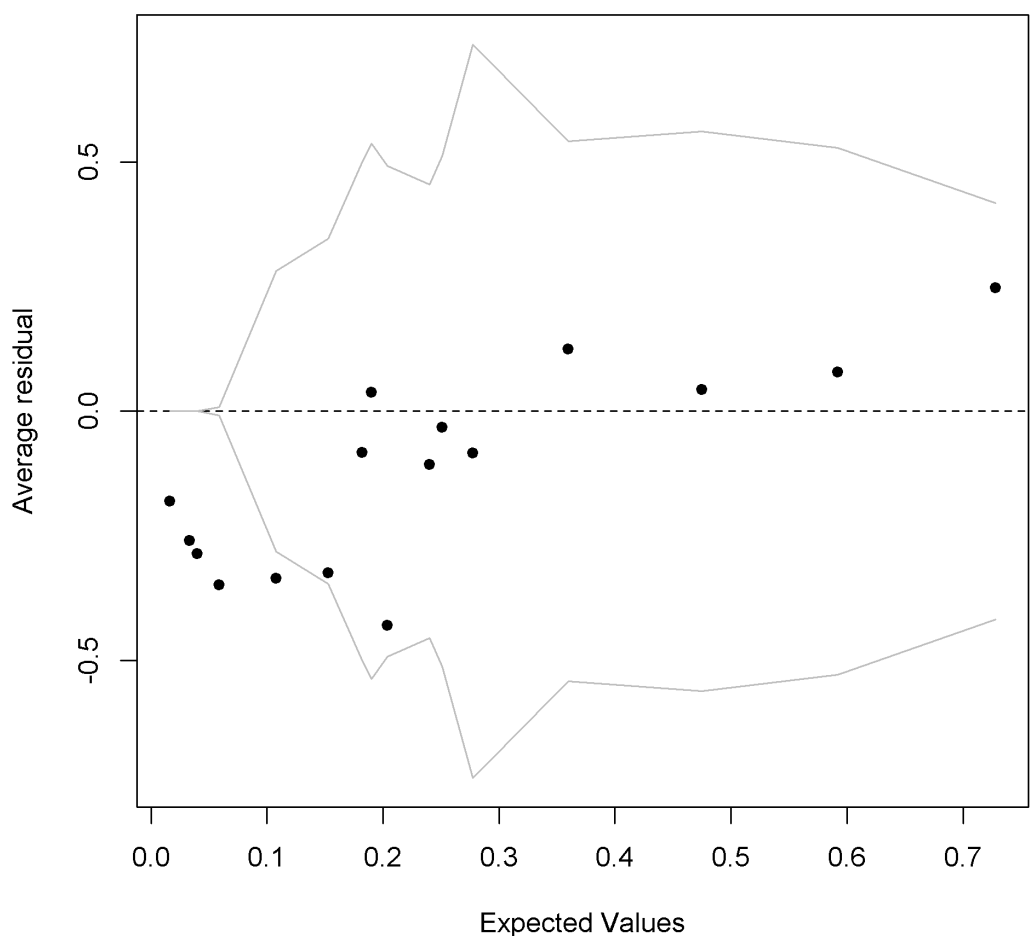

Figure A2. Residuals of the linear model used to model seedlings relative growth rate in height. The analysis of models' residuals showed that conditions for normality, homoscedasticity, and independency between observations were correctly met. All observations had Cook's distances $<1$ indicating that no outliers influenced coefficient estimates.

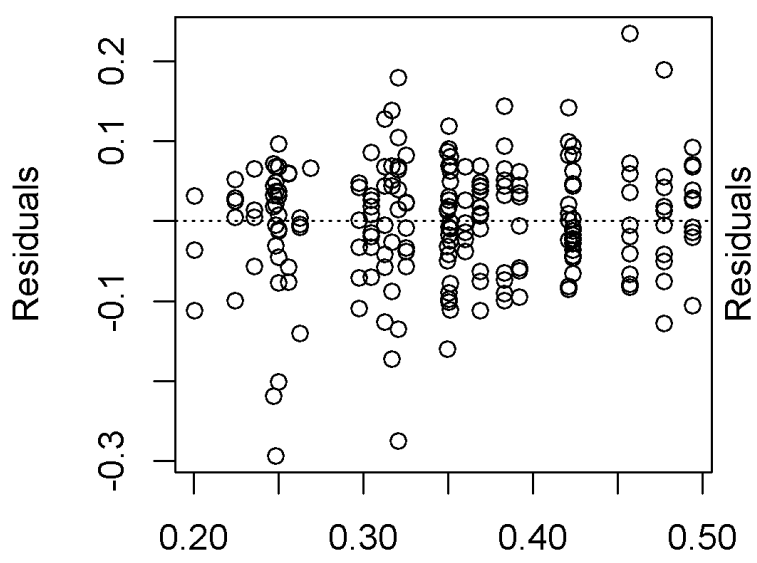

Fitted values

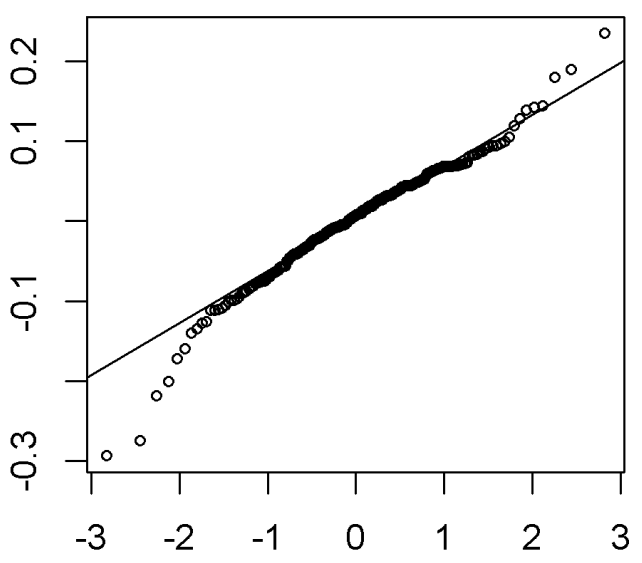

Theoretical quantiles 
Figure A3. Residuals of the linear model used to model seedlings relative growth rate in diameter. The analysis of models' residuals showed that conditions for normality, homoscedasticity, and independency between observations were correctly met. All observations had Cook's distances $<1$ indicating that no outliers influenced coefficient estimates.

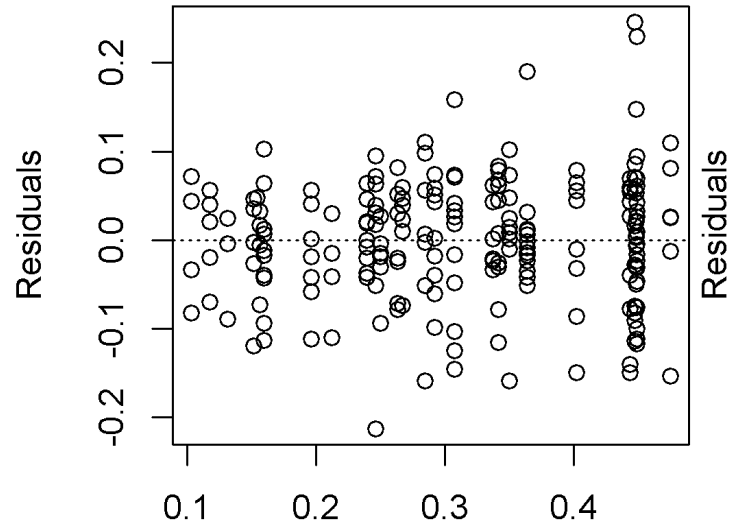

Fitted values

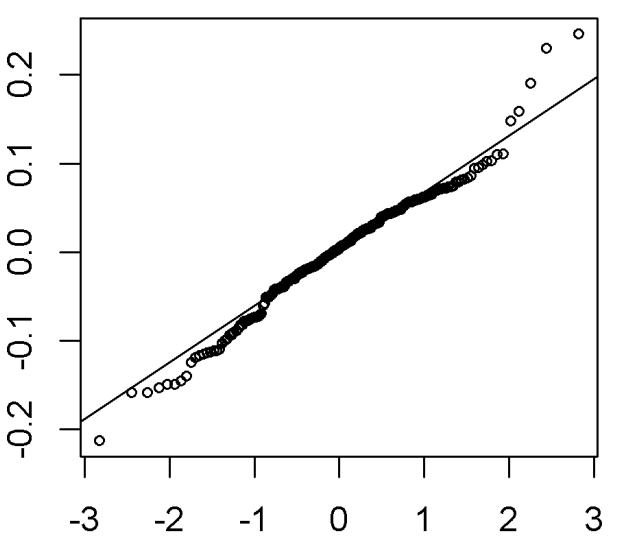

Theoretical quantiles

Table A1. For each site, mean and standard deviation ( $s d$ ) of soil \% clay, sand, and silt, \% organic matter, $\mathrm{pH} \mathrm{H}_{2} \mathrm{O}, \mathrm{pH} \mathrm{KCl}$, bulk density, and content of $\mathrm{P}, \mathrm{K}, \mathrm{Ca}, \mathrm{Mg}$, $\mathrm{Al}$ and $\mathrm{H}$ are given. The letters indicate significant differences between sites (Nemenyi-Damico-Wolfe-Dunn multiple comparison tests, $p$-value $<0.05$ ).

\begin{tabular}{|c|c|c|c|c|}
\hline Soil variable & & Site 1 & Site 2 & Site 3 \\
\hline \multirow[t]{2}{*}{$\%$ clay } & mean & $42.97^{\mathrm{a}}$ & $61.89^{b}$ & $67.11^{b}$ \\
\hline & $s d$ & 7.15 & 2.93 & 4.98 \\
\hline \multirow[t]{2}{*}{$\%$ sand } & mean & $43.61^{\mathrm{a}}$ & $33.52^{\mathrm{ab}}$ & $25.71^{b}$ \\
\hline & $s d$ & 6.74 & 3.58 & 4.12 \\
\hline \multirow[t]{2}{*}{$\%$ silt } & mean & $13.46^{\mathrm{a}}$ & $4.59^{b}$ & $7.16^{\mathrm{b}}$ \\
\hline & $s d$ & 2.62 & 1.88 & 1.90 \\
\hline \multirow[t]{2}{*}{$\%$ organic matter } & mean & $5.18^{\mathrm{a}}$ & $6.72^{\mathrm{b}}$ & $7.33^{b}$ \\
\hline & $s d$ & 0.76 & 1.38 & 0.84 \\
\hline \multirow[t]{2}{*}{$\mathrm{pH} \mathrm{H} \mathrm{H}_{2} \mathrm{O}$} & mean & $3.99^{\mathrm{a}}$ & $3.98^{\mathrm{a}}$ & $4.11^{\mathrm{a}}$ \\
\hline & $s d$ & 0.09 & 0.12 & 0.13 \\
\hline \multirow[t]{2}{*}{$\mathrm{pH} \mathrm{KCl}$} & mean & $3.87^{\mathrm{a}}$ & $4.09^{b}$ & $4.13^{b}$ \\
\hline & $s d$ & 0.11 & 0.21 & 0.10 \\
\hline \multirow{2}{*}{$\begin{array}{l}\text { Bulk density } \\
\qquad\left(\mathrm{g} / \mathrm{cm}^{3}\right)\end{array}$} & mean & $1.21^{\mathrm{a}}$ & $1.02^{\mathrm{b}}$ & $1.02^{\mathrm{b}}$ \\
\hline & $s d$ & 0.05 & 0.03 & 0.09 \\
\hline $\mathrm{P}$ & mean & $2.48^{\mathrm{a}}$ & $2.90^{\mathrm{a}}$ & $2.08^{\mathrm{a}}$ \\
\hline$(\mu \mathrm{g} / \mathrm{g})$ & $s d$ & 0.52 & 1.06 & 0.52 \\
\hline $\mathrm{K}$ & mean & $0.14^{\mathrm{a}}$ & $0.08^{b}$ & $0.10^{\mathrm{ab}}$ \\
\hline$\left(\mathrm{cmol}_{\mathrm{c}} / \mathrm{kg}\right)$ & $s d$ & 0.04 & 0.02 & 0.02 \\
\hline $\mathrm{Ca}$ & mean & $0.32^{\mathrm{a}}$ & $0.41^{\mathrm{a}}$ & $0.64^{\mathrm{a}}$ \\
\hline$\left(\mathrm{cmol}_{\mathrm{d}} / \mathrm{kg}\right)$ & $s d$ & 0.21 & 0.17 & 0.34 \\
\hline $\mathrm{Mg}$ & mean & $0.18^{\mathrm{a}}$ & $0.23^{\mathrm{a}}$ & $0.26^{\mathrm{a}}$ \\
\hline$\left(\mathrm{cmol}_{\mathcal{C}} / \mathrm{kg}\right)$ & $s d$ & 0.06 & 0.08 & 0.09 \\
\hline $\mathrm{Al}$ & mean & $3.03^{\mathrm{a}}$ & $1.60^{\mathrm{b}}$ & $1.26^{\mathrm{b}}$ \\
\hline$\left(\mathrm{cmol}_{\mathrm{d}} / \mathrm{kg}\right)$ & $s d$ & 1.07 & 0.47 & 0.61 \\
\hline $\mathrm{H}$ & mean & $0.86^{\mathrm{a}}$ & $0.40^{\mathrm{b}}$ & $0.35^{b}$ \\
\hline$\left(\mathrm{cmol}_{\mathrm{c}} / \mathrm{kg}\right)$ & $s d$ & 0.30 & 0.22 & 0.27 \\
\hline
\end{tabular}




\section{Conflicts of Interest}

The authors declare no conflict of interest.

\section{References}

1. Sist, P.; Gourlet-Fleury, S.; Putz, F.E. The impacts of selective logging: Questionable conclusions. BioScience 2012, 62, 786-786.

2. Fargeot, C.; Forni, E.; Nasi, R. Réflexion sur l'aménagement des forêts de production dans le bassin du Congo. Bois For. Trop. 2004, 281, 19-34.

3. Karsenty, A.; Gourlet-Fleury, S. Assessing sustainability of logging practices in the Congo Basin's managed forests: The issue of commercial species recovery. Ecol. Soc. 2006, 11, 26.

4. Gourlet-Fleury, S.; Mortier, F.; Fayolle, A.; Baya, F.; Ouédraogo, D.; Bénédet, F.; Picard, N. Tropical forest recovery from logging: A 24 year silvicultural experiment from Central Africa. Philos. Trans. R. Soc. B Biol. Sci. 2013, 368, doi:10.1098/rstb.2012.0302.

5. Hawthorne, W.D. Ecological Profiles of Ghanaian Forest Trees; Oxford Forestry Institute, Department of Plant Sciences, University of Oxford: Oxford, UK, 1995.

6. Doucet, J.L. L'alliance délicate de la gestion forestière et de la biodiversité dans les forêts du centre du Gabon. Ph.D. Thesis, Faculté Universitaire des Sciences agronomiques de Gembloux, Gembloux, Belgium, 2003.

7. Makana, J.R.; Thomas, S.C. Effects of light gaps and litter removal on the seedling performance of six African timber species. Biotropica 2005, 37, 227-237.

8. Makana, J.R.; Thomas, S.C. Impacts of selective logging and agricultural clearing on forest structure, floristic composition and diversity, and timber tree regeneration in the Ituri Forest, Democratic Republic of Congo. Biodivers. Conserv. 2006, 15, 1375-1397.

9. Doucet, J.-L.; Kouadio, Y.L.; Monticelli, D.; Lejeune, P. Enrichment of logging gaps with moabi (Baillonella toxisperma Pierre) in a Central African rain forest. For. Ecol. Manag. 2009, 258, 2407-2415.

10. Brokaw, N.V.L. Gap-phase regeneration in a tropical forest. Ecology 1985, 66, 682-687.

11. Kyereh, B.; Swaine, M.D.; Thompson, J. Effect of light on the germination of forest trees in Ghana. J. Ecol. 1999, 87, 772-783.

12. Babaasa, D.; Eilu, G.; Kasangaki, A.; Bitariho, R.; McNeilage, A. Gap characteristics and regeneration in Bwindi Impenetrable National Park, Uganda. Afr. J. Ecol. 2004, 42, 217-224.

13. Keefe, K.; Alavalapati, J.A.A.; Pinheiro, C. Is enrichment planting worth its costs? A financial cost-benefit analysis. For. Policy Econ. 2012, 23, 10-16.

14. Schwartz, G.; Lopes, J.C.A.; Mohren, G.M.J.; Peña-Claros, M. Post-harvesting silvicultural treatments in logging gaps: A comparison between enrichment planting and tending of natural regeneration. For. Ecol. Manag. 2013, 293, 57-64.

15. Owona Ndongo, P.-A.; Peltier, R.; Linjouom, I.; Louppe, D.; Smektala, G.; Beligne, V.; Njoukam, R.; Tieche, B.; Temgoua, L. Plantations de bois d'oeuvre en zone équatoriale africaine: Cas de l'arboretum de l'Enef de Mbalmayo au sud du Cameroun. Bois For. Trop. 2009, 299, 37-48. 
16. Doucet, J.-L.; Ntchandi Otimbo, P.-A.; Boubady, A.-G. Assisting natural regeneration of Okoume populations in logging concessions? Bois For. Trop. 2004, 279, 59-71.

17. Bosu, P.P.; Cobbinah, J.R.; Nichols, J.D.; Nkrumah, E.E.; Wagner, M.R. Survival and growth of mixed plantations of Milicia excelsa and Terminalia superba 9 years after planting in Ghana. For. Ecol. Manag. 2006, 233, 352-357.

18. Opuni-Frimpong, E.; Karnosky, D.F.; Storer, A.J.; Cobbinah, J.R. Silvicultural systems for plantation mahogany in Africa: Influences of canopy shade on tree growth and pest damage. For. Ecol. Manag. 2008, 255, 328-333.

19. African Regional Workshop. IUCN red List threat species version. In Proceedings of the Conservation \& Sustainable Management of Trees, Pericopsis elata, Harare, Zimbabwe, July 1996. Available online: http:// www.iucnredlist.org (accessed on 1 October 2014).

20. Bourland, N.; Kouadio, Y.L.; Lejeune, P.; Sonké, B.; Phillipart, J.; Daïnou, K.; Fétéké, F.; Doucet, J.-L. Ecology of Pericopsis elata (Fabaceae), an Endangered Timber Species in Southeastern Cameroon. Biotropica 2012, 44, 840-847.

21. Bourland, N.; Kouadio, Y.L.; Fétéké, F.; Lejeune, P.; Doucet, J.-L. Ecology and management of Pericopsis elata (Harms) Meeuwen (Fabaceae) populations: A review. Biotechnol. Agron. Soc. Environ. 2012, 16, 486-498.

22. Schulze, M. Technical and financial analysis of enrichment planting in logging gaps as a potential component of forest management in the eastern Amazon. For. Ecol. Manag. 2008, 255, 866-879.

23. Hijmans, R.J.; Cameron, S.E.; Parra, J.L.; Jones, P.G.; Jarvis, A. Very high resolution interpolated climate surfaces for global land areas. Int. J. Climatol. 2005, 25, 1965-1978.

24. Letouzey, R. Carte Phytogéographique du Cameroun; Institut de la Recherche Agronomique: Paris, France, 1985.

25. Fayolle, A.; Picard, N.; Doucet, J.-L.; Swaine, M.; Bayol, N.; Bénédet, F.; Gourlet-Fleury, S. A new insight in the structure, composition and functioning of central African moist forests. For. Ecol. Manag. 2014, 329, 195-205.

26. ATIBT. Association Technique Internationale des Bois Tropicaux Statistiques 2010. La Lettre de L'ATIBT 2012, 34, 1-45.

27. Veenendaal, E.M.; Swaine, M.D.; Lecha, R.T.; Walsh, M.F.; Abebrese, I.K.; Owusu-Afriyie, K. Responses of West African forest tree seedlings to irradiance and soil fertility. Funct. Ecol. 1996, 10, 501-511.

28. Swaine, M.D.; Hall, J.B. The mosaic theory of forest regeneration and the determination of forest composition in Ghana. J. Trop. Ecol. 1988, 4, 253-269.

29. Boyemba, F. Écologie de Pericopsis elata (Harms) Van Meeuwen (Fabaceae), arbre de forêt tropicale africaine à répartition agrégée. Ph.D. Thesis, Université libre de Bruxelles, Brussels, Belgium, 2011.

30. Hardy, O.J.; Born, C.; Budde, K.; Daïnou, K.; Dauby, G.; Duminil, J.; Ewédjé, E.-E.B.; Gomez, C.; Heuertz, M.; Koffi, G.K. Comparative phylogeography of African rain forest trees: A review of genetic signatures of vegetation history in the Guineo-Congolian region. Comptes Rendus Geosci. 2013, 345, 284-296.

31. Pansu, M.; Gautheyrou, J. Handbook of Soil Analysis: Mineralogical, Organic and Inorganic Methods; Springer: Berlin, Germany, 2007. 
32. Hollander, M.; Wolfe, D.A. Nonparametric Statistical Methods; John Wiley \& Sons: New York, NY, USA, 1999.

33. R Core Team. R: A Language and Environment for Statistical Computing; R Foundation for Statistical Computing: Vienna, Austria, 2013.

34. Sheil, D.; Burslem, D.F.; Alder, D. The interpretation and misinterpretation of mortality rate measures. J. Ecol. 1995, 83, 331-333.

35. Hunt, R.; Thomas, B.; Murphy, D.J.; Murray, D. Growth analysis, individual plants. Encycl. Appl. Plant Sci. 2003, 2, 579-588.

36. Nakagawa, S.; Schielzeth, H. A general and simple method for obtaining $R^{2}$ from generalized linear mixed-effects models. Methods Ecol. Evol. 2013, 4, 133-142.

(C) 2014 by the authors; licensee MDPI, Basel, Switzerland. This article is an open access article distributed under the terms and conditions of the Creative Commons Attribution license (http://creativecommons.org/licenses/by/4.0/). 